\title{
Interferon Regulatory Factor 2-Binding Protein 2
}

National Cancer Institute

\section{Source}

National Cancer Institute. Interferon Regulatory Factor 2-Binding Protein 2. NCI

Thesaurus. Code C107666.

Interferon regulatory factor 2-binding protein 2 (587 aa, $\sim 61 \mathrm{kDa}$ ) is encoded by the human IRF2BP2 gene. This protein plays a role in the negative regulation of interferon expression. 